\title{
ANALYSIS OF ENERGY UTILISATION IN MALAYSIAN OIL PALM MECHANISATION OPERATION
}

\author{
AZWAN, M B*; NORASIKIN, A L**; ABD RAHIM, S*; NORMAN, $K^{\star}$ and SALMAH, J*
}

\begin{abstract}
The aim of this study is to examine the energy used in Malaysian oil palm plantation operations, especially on fuel consumption in farm mechanisation practices. This benchmark study was conducted based on the energy input-output methodology. The results found that 258 GJ of input energy was required to produce 20 tha $\mathrm{g}^{-1} \mathrm{yr}^{-1}$ of fresh fruit bunches (FFB). The energy was dominated by chemical fertilisers (66\%), followed by labour (21\%), machinery (10\%), fuel consumption (2\%), and chemical herbicide ( $0.5 \%)$, with an energyuse efficiency of $62 \%$. A survey on the fuel consumption in the mechanisation practices was conducted at

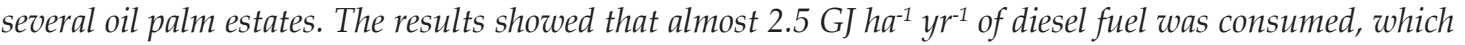
is equivalent to greenhouse gas (GHG) emissions of approximately $133 \mathrm{~kg} \mathrm{CO}_{2}$-eq ha $\mathrm{hr}^{-1}$. The economic indicator was also studied to consider the types of energy improvement initiative that should be taken. This study suggested utilising renewable energy and greener energy technology such as electric powertrain charged via renewable energy source for farm mechanisation operations. It is expected that almost $9.8 \mathrm{~kg}$ $\mathrm{CO}_{2}$-eq ha-1 $\mathrm{yr}^{-1}$ of GHG emission saving and a significant amount of improvement in operational costs could be achieved by utilising the technology.
\end{abstract}

Keywords: oil palm mechanisation, energy consumption, GHG emission.

Date received: 30 March 2016; Sent for revision: 17 March 2016; Received in final form: 14 August 2016 ; Accepted: 29 August 2016.

\section{INTRODUCTION}

Oil palm mechanisation operation has the possibility of reducing labour dependency, increasing farm productivity, and hastening field operations (Abd Rahim et al., 2010). Field mechanisation can be defined as working systems that involve the interaction between machines and operators to accomplish certain work activities. It is an advancement in field operations that first started with the invention of the farm tractor (Singh and Mittal, 1992). However, each machine is not suited

\footnotetext{
* Malaysian Palm Oil Board,

6 Persiaran Institusi, Bandar Baru Bangi,

43000 Kajang, Selangor, Malaysia.

E-mail: azwan.bakri@mpob.gov.my

** Solar Energy Research Institute,

Universiti Kebangsaan Malaysia,

43600 Bangi, Selangor, Malaysia.
}

to be used in all areas, climatic conditions, soil types, and topographies. Thus, different machines were designed and fabricated to suit local requirements and conditions (Abd Rahim et al., 2008a).

Mechanisation has been adopted in the Malaysian oil palm plantation operations since the early 1960s but may be limited to only specific activities. Lately, however, it has gained more interest and participation from the industry because the production of better quality oil crop and faster evacuation of fresh fruit bunches (FFB) from the palm base to the processing mills are required. Scarcity of labour in the industry, requires wider adaptation of mechanisation. Oil palm field operations are labour-intensive, whereby sources of labour mostly come from neighbouring countries. Figure 1 depicts the job categories with local and foreign workers in the Malaysian oil palm plantations (Ludin et 


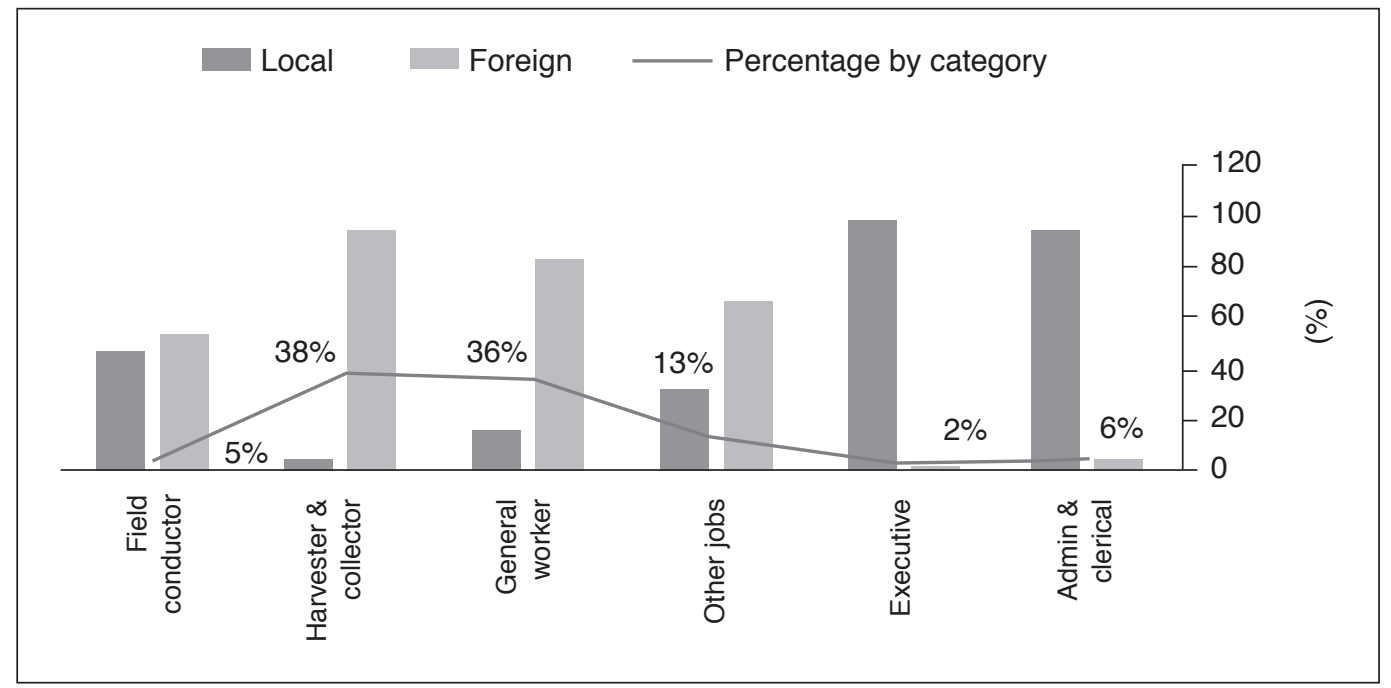

Source: Azman and Simeh (2012).

Figure 1. Job category in Malaysian oil palm plantation operation.

al., 2014). High dependency on foreign workers will be problematic, especially when its supply line is interrupted due to competitive labour demand from other countries or industries. Interruption is expected to cause unfavourable conditions to the industry if mechanisation is not highly pursued.

Most of the farm machinery required in matured oil palm plantations are used for hauling FFB from palm bases to a collection centre, as well as a palm oil mill. They are also intensively used in transporting workers, carrying agriculture inputs, spreading fertiliser, maintaining roads and drainage systems, spraying herbicides or pesticides, and evacuating loose fruits. Currently, mechanisations are not economically viable for smallholders to practice, except farms that are under a particular organised scheme (Azman and Simeh, 2012).

Besides tractors, several farm machines have been developed for certain oil palm plantation activities, especially to evacuate FFB and loose fruits, spreading fertiliser, and spraying chemicals. The size of the machines and tractors used in oil palm plantations activities, especially in evacuating FFB and loose fruit from palm bases to a collection point, are below $100 \mathrm{hp}$. The average size and power are adequate since the payload is between 3 to $50 \mathrm{t}$ per trip (Abd Rahim et al., 2008b). Besides that, farm roads are usually designed not for a heavy load. Table 1 lists the activities in the different oil palm plantation sectors by the various methods.

Most of the machines are powered by diesel fuel. Theoretically, these mechanical machines can convert $20 \%$ of the energy contained in the fuel to mechanical energy and work effectively within its optimal load and conditions. Thus, selecting and managing the machines are important aspects of reducing wastage, increasing profitability, and reduce environmental effects.
A life cycle analysis (LCA) conducted by the Malaysian Palm Oil Board (MPOB) indicated that diesel fuel and machinery could have an impact on the environment (Zulkifli et al., 2010). The study was conducted based on a normal oil palm plantation operation under continuous land use. The impact is related to greenhouse gasses (GHG) emissions while operating the machinery. Thus, it is crucial to analyse the situation to reduce the negative impact on the environment and to improve the sustainability of the industry. Energy analysis was conducted to estimate energy efficiency in crop production and could subsequently provide significant points for saving energy.

Several studies were carried out on energy consumption in other agriculture productions, its relationship with the environment and the level of mechanisation (Pishgar et al., 2012; Morteza et al., 2010; Sahr et al., 2005; Shirazi et al., 2012; Avval et al., 2012; Polat et al., 2006; Sanglam et al., 2012; Monjezi and Zakidizaji, 2012). Most of these studies suggested an increase in renewable energy source portions in their farming operations. Thus, even with a small initiative taken, it will result in increasing the sustainability of the industry. Since there is currently almost 4500 registered oil palm estates in Malaysia (MPOB, 2014), a small portion of renewable energy source incorporated in their daily tasks will lead to significant impacts.

In the oil palm plantation sector, energy used for operations can be classified as direct and indirect sources. Direct sources include diesel or gasoline fuels, human power, animal energy, fertilisers and chemicals. The direct source of energy indicates that the energy is released directly into the agricultural activity, while the indirect source of energy refers to the source of energy that is not directly put into agricultural activity but released through a 
TABLE 1. OPERATION IN OIL PALM PLANTATION ACTIVITIES

\begin{tabular}{|c|c|c|c|c|c|}
\hline Road maintenance & Light maintenance & & 40 & $\mathrm{~km} \mathrm{md}^{-1}$ & Corley and Tinker (2003) \\
\hline & $\begin{array}{l}\text { Light weed infestation } \\
\text { Heavy weed infestation }\end{array}$ & $\begin{array}{l}\text { Knapsack pump } \\
\text { Knapsack pump }\end{array}$ & $\begin{array}{l}10 \\
3.5\end{array}$ & $\begin{array}{l}\text { ha } \mathrm{md}^{-1} \\
\text { ha } \mathrm{md}^{-1}\end{array}$ & $\begin{array}{l}\text { Rankine et al. (1998) } \\
\text { Rankine et al. (1998) }\end{array}$ \\
\hline $\begin{array}{l}\text { Fertiliser } \\
\text { application }\end{array}$ & General fertiliser & $\begin{array}{l}\text { Tractor mounted } \\
\text { spreader }\end{array}$ & 3.4 & ha md $\mathrm{m}^{-1}$ & Turner and Gillbanks (2003) \\
\hline Harvesting & (1 harvester \& 1 helper) & $\begin{array}{l}\text { Motorised cutter } \\
\text { Manual pole }\end{array}$ & $\begin{array}{l}6 \\
2\end{array}$ & $\begin{array}{l}\text { ha md }{ }^{-1} \\
\text { ha } \mathrm{md}^{-1}\end{array}$ & $\begin{array}{l}\text { Rahim et al. (2009) } \\
\text { Rahim et al. (2009) }\end{array}$ \\
\hline FFB transport & Mainline & $\begin{array}{l}\text { Tractor Grabber } \\
\text { Small machine } \\
\text { Wheelbarrow }\end{array}$ & $\begin{array}{c}25 \\
6 \\
1 \\
73.5\end{array}$ & $\begin{array}{l}\text { ha } \mathrm{md}^{-1} \\
\text { ha } \mathrm{md}^{-1} \\
\text { ha } \mathrm{md}^{-1} \\
\text { ha } \mathrm{md}^{-1}\end{array}$ & $\begin{array}{l}\text { Rahim et al. (2008a) } \\
\text { Awaluddin et al. (2015) } \\
\text { Awaluddin et al. (2015) } \\
\text { Corley and Tinker (2003) }\end{array}$ \\
\hline
\end{tabular}

Note: ha $\mathrm{md}^{-1}$ is hectare per man day and $\mathrm{km} \mathrm{md}^{-1}$ is kilometres per man day.

FFB - fresh fruit bunches.

conversion process. An example of an indirect source of energy is machinery. Energy input for machinery refers to the energy requirement in producing the machine instead of the energy required to operate the machinery. Energy to operate the machinery can be classified as energy input from human labour.

Energy and economic relationships have been studied by various researchers. They indicated a correlation between the energy and investment put into agriculture practices that determine its profitability as the cost of energy increases significantly over time. In the case of oil palm plantation industries, chemical fertiliser has contributed significantly to the cost of agriculture input. More than $60 \%$ of FFB production cost comprises of fertiliser expenses (Azman et al., 2003).

This article aims to analyse energy usage patterns in oil palm plantation operations, especially in mechanisation operations by utilising energy indices such as input, output, specific, and net energy in the oil palm plantation sector. Thus, a more efficient manner of energy utilisation can be determined and initiated for financial saving or environmental benefits.

\section{METHODOLOGY}

The study was divided into two segments. The first segment analysed the overall energy input-output of FFB production. The study had simulated a plantation that was assumed to have optimum farm mechanisation practices. It was conducted to have an overview of energy efficiency in the plantation with full mechanisation practices. Therefore, a general energy analysis methodology proposed by Fluck (1991) was utilised in this study, as shown in Figure 2. Economic analysis was conducted to assess the financial viability of the FFB production. Most of the input data were sought through literature and estimated to suit the scenario.

Secondly, the study specifically focused on the energy used in oil palm mechanisation operations, especially on its fuel consumption. Actual energy utilisation in the Malaysian oil palm mechanisation operations was gathered through a survey that was distributed to some major oil palm plantations throughout the country. This study was conducted from March to September 2014. About 30 estates were approached and provided with a set of questionnaire. Several study visits were also conducted to some estates to observe their daily operation especially on the estates that practiced mechanisation. Only eight estates provided their response towards the questionnaire, mainly because other estates had outsourced their field operations to contractors and therefore no proper recording on fuel consumption for designated work area were made. Those eight estates are scattered throughout the country and represented various management approached in mechanisation practice. Even though the rate of diesel consumption differs based on topography, soil types and conditions, maintenance schedule, operator skills and machine's conditions; this study could only analyze the average input 


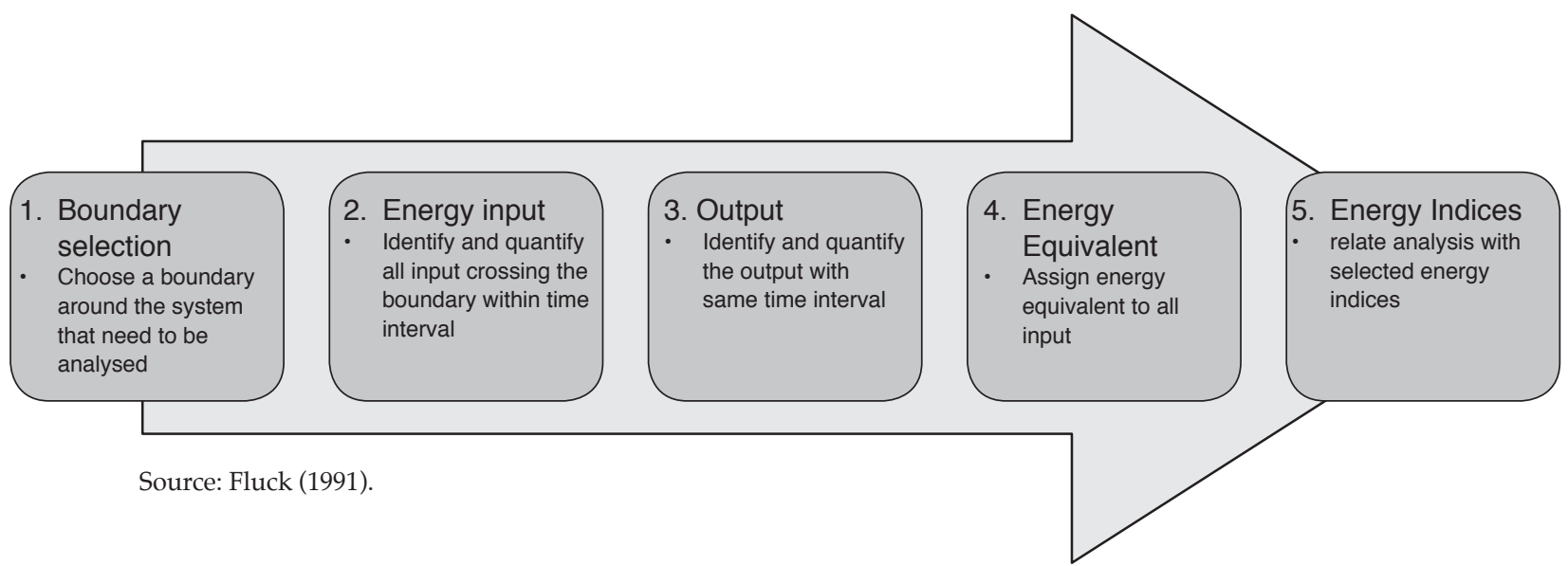

Figure 2. Proposed energy analysis methodology.

available to assess potential improvement for the energy utilisation.

The data on energy consumption for specific farm mechanisation operations and trends of mechanisation practices were obtained from the questionnaire. Thus, the specific area of utilisation could be analysed and suggested for future improvement. An analysis of GHG emission was also conducted to benchmark the emission from the diesel fuel consumption of farming machinery. The GHG emission rate $\left(\mathrm{GHG}_{\text {rate }}\right)$ was obtained by multiplying the GHG coefficients factor $\left(\mathrm{Ef}_{\mathrm{GHG}}\right)$ with the rate of diesel fuel consumption (Diesel ${ }_{\text {rate }}$ ) as shown in Equation (1). Meanwhile, the energy unit can be converted from the volume of diesel fuel consumed (Diesel ${ }_{\text {vol }}$ ) by multiplying the figures with the energy equivalent coefficient (Diesel ${ }_{\mathrm{eq}}$ ) in producing of FFB that was taken at $36 \mathrm{MJ}^{\text {litre }}{ }^{-1}$ (Nikander, 2008) as in Equation (2).

$$
\begin{aligned}
& \mathrm{GHG}_{\text {rate }}=\mathrm{Ef}_{\mathrm{GHG}_{1}}\left(\mathrm{~kg} \mathrm{CO}_{2} \text {-eq litre }{ }^{-1}\right) \times \text { Diesel }_{\text {rate }}\left(\text { litre ha }^{-1}\right) \\
& \text { Energy in the fuel }(\mathrm{MJ})=\text { Diesel }_{\mathrm{eq}}\left(\mathrm{MJ} \mathrm{litre}^{-1}\right) \times \text { Diesel }_{\text {vol }}(\text { litre })
\end{aligned}
$$

For the first methodology, the results were acquired from energy input $\left(\mathrm{E}_{\mathrm{IN}}\right)$ and energy output $\left(\mathrm{E}_{\mathrm{OUT}}\right)$ ratio, energy productivity, specific energy, and net energy. The indices, such as energy ratio $\left(\mathrm{E}_{\text {RATIO }}\right)$, energy productivity ( $\left.\mathrm{E}_{\text {PRODUCTIVITY }}\right)$, specific energy $\left(\mathrm{E}_{\text {SPECIFIC }}\right)$, and net energy $\left(\mathrm{E}_{\text {NET }}\right)$, were obtained by following Equations (3), (4), (5), and (6).

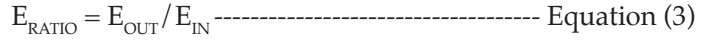

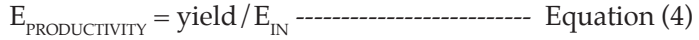

$$
\begin{aligned}
& \mathrm{E}_{\text {SPECIFIC }}=1 / \mathrm{E}_{\text {PRODUCTIVITY }} \text {------------------------ Equation (5) } \\
& \mathrm{E}_{\mathrm{NET}}=\mathrm{E}_{\mathrm{OUT}}-\mathrm{E}_{\mathrm{IN}} \text { - - }
\end{aligned}
$$

Economic analysis was investigated by studying its total production value, net return, the benefit to cost ratio, and productivity cost. The data for the FFB price, yield, and estimate total production cost were sought from ERE (2012) and Azman et al. (2003). The methods to calculate the mentioned economic indicators are shown below, with the monetary value in Ringgit Malaysia (RM):

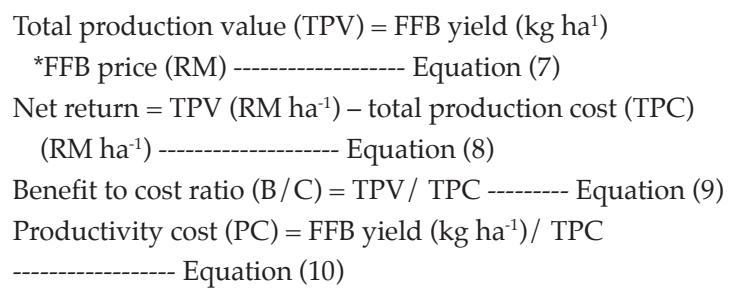

Five main steps of energy analysis were undertaken in the study, as shown in Figure 2. The first step was to determine the boundary of the study, while the next step is to identify and quantify the input and output from the selected area. Third and fourth steps include converting all input and output data into an energy unit $\left(\mathrm{E}_{\mathrm{IN}}\right.$ and $\left.\mathrm{E}_{\mathrm{OUT}}\right)$. The final results produced the indication of energy performance through energy indices obtained from the analysis. The output parameter was the FFB yield in a year. By-products such as fronds or other biomass were not considered for this study.

Figure 3 depicts the boundary for this study, which was an oil palm plantation model. The bound ary covered only planted areas and excluded the nursery, office, and workers' quarters. The plantation model had dedicated machinery for all the plantation activities: a mounted sprayer machine for the herbicide spraying, fertiliser spreader for fertiliser application, locally-made farm utility vehicle for FFB evacuation, and a 90-hp tractor with 10-t bin for mainline FFB transportation.

Some common and acceptable parameters by the industry were obtained through a review of 


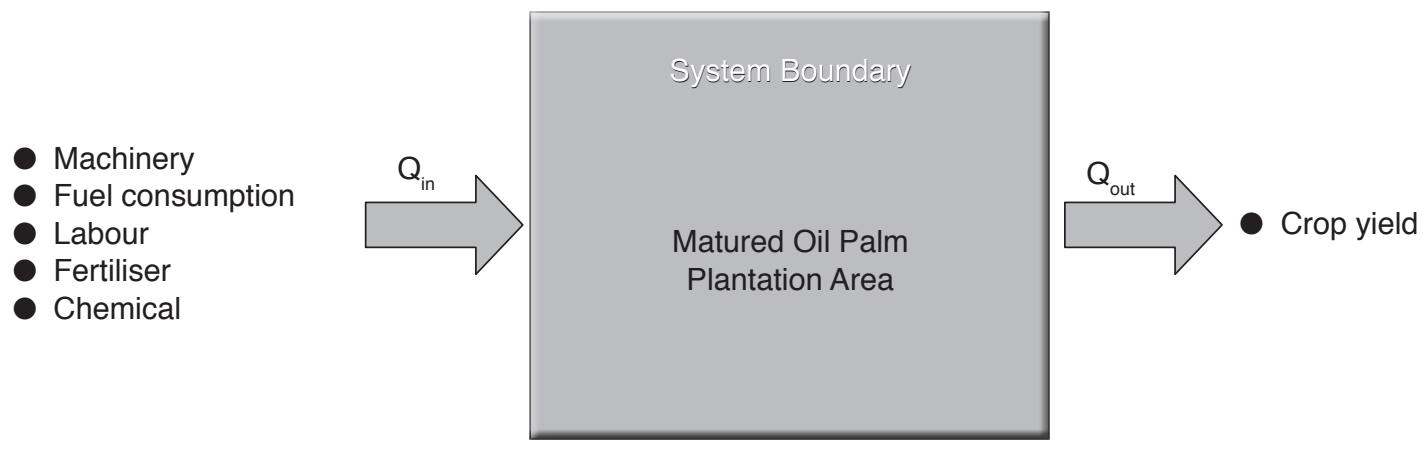

Figure 3. Diagram of boundary, input and output for the study.

existing literature and listed in Table 2. They were also used as input data. Most of the assumptions were on a yearly basis. Even though the yield of the FFB differs from young to prime and old palms, the figure was accepted for an indicative purpose. The energy equivalent for FFB has taken on the wet matter, which is lower than $10 \mathrm{MJ} \mathrm{kg}^{-1}$. This is because FFB contains $85 \%$ moisture (Rahman et al., 2013). As for human labour, the productivity shown in Table 2 was converted into the time consumed in covering a hectare of the plantation. This value was then multiplied with the labour to land ratio, which is $0.1 \mathrm{man} \mathrm{ha}^{-1}$ (Zulkifli et al., 2014) to obtain the quantity per unit area required in the analysis.

The input data specified in Tables 1 and 2 were used to calculate and estimate the quantity per unit area that indicated the input of agriculture crosses the boundary based on hours (hr) and mass (kg) consumed per unit area (ha) as in Table 4. Meanwhile, energy equivalent is the indicator of the mass of an object or system in measuring its energy content in Joule (J) or MJ. The energy equivalent coefficient as in Table 3 was obtained through the literature reviews (Shirazi et al., 2012; Pishgar et al., 2012; Avval et al., 2012; Sanglam et al., 2012; Monjezi and Zakidizaji, 2012). Thus, the energy analysis was calculated based on the quantity of input and output per unit area and multiplied with energy equivalent coefficient shown in Table 3.

\section{RESULTS AND DISCUSSION}

\section{Energy Input - Output Analysis for FFB Production}

The results of the input and output energy in FFB production are shown in Table 4. It indicated that the energy input and output were about 258 GJ ha-1 and $160 \mathrm{GJ} \mathrm{ha}^{-1}$ respectively. More than $66 \%$ of the energy input was contributed from chemical fertiliser application, which is the main requirement for the oil palm, either for its growth or for producing the FFB. Energy from human labour contributed about $21 \%$ of the total energy input. Meanwhile, the energy required for diesel consumption is $2 \%$ and the energy needed for the machinery is about $10.8 \%$ of the total energy required. Finally, the energy from chemical herbicides and pesticides contributed only $0.5 \%$ of the total energy input. It can be concluded that the energy consumed as input energy is dominated by chemical fertilisers. A lot of the energy is required in producing FFB and also to support the palms' growth, which could generally reach more than $20 \mathrm{~m}$ of its maximum height and also produce other biomass such as fronds, leaves, and trunks (Yusof, 2007). The results also justified the previous study which indicated that more than $60 \%$ of the cost of FFB production was contributed by chemical fertilisers. The recommended chemical or compound (NPK) fertiliser requirements is generally between $9-13 \mathrm{~kg}$ palm ${ }^{-1} \mathrm{yr}^{-1}$ to produce

TABLE 2. ASSUMPTION FOR THE ENERGY INPUT/OUTPUT ANALYSIS

\begin{tabular}{lccc}
\hline Input/output & Quantity & Unit & Reference \\
\hline Herbicide and pesticide use & 5 & $\mathrm{~kg} \mathrm{ha}^{-1} \mathrm{yr}^{-1}$ & Rankine et al. (1998) \\
Fertiliser use & 13 & $\mathrm{~kg} \mathrm{palm}^{-1} \mathrm{yr}^{-1}$ & Zulkifli et al. (2010) \\
Labour & 14.5 & $\mathrm{~h} \mathrm{hr}^{-1} \mathrm{man}^{-1}$ & Darius et al. (2012) \\
Diesel consumption & 3.2 & $\mathrm{GJ} \mathrm{ha}^{-1} \mathrm{yr}^{-1}$ & Zulkifli et al. (2010) \\
Average FFB yield & 20000 & $\mathrm{~kg} \mathrm{ha}^{-1} \mathrm{yr}^{-1}$ & Zulkifli et al. (2010) \\
\hline
\end{tabular}

Note: FFB - fresh fruit bunches. 


\begin{tabular}{|c|c|c|}
\hline Input/output & Unit & $\begin{array}{l}\text { Energy equivalent } \\
\quad\left(\mathrm{MJ} \text { unit }^{-1}\right)\end{array}$ \\
\hline \multicolumn{3}{|l|}{ A. Input } \\
\hline Human labour & $\mathrm{hr}$ & 1.96 \\
\hline Machinery & $\mathrm{hr}$ & 62.7 \\
\hline Chemical fertiliser (NPK) & $\mathrm{kg}$ & 89.73 \\
\hline Herbicide & $\mathrm{kg}$ & 238 \\
\hline Diesel fuel & litre & 56.3 \\
\hline \multicolumn{3}{|l|}{ B. Output } \\
\hline FFB & $\mathrm{kg}$ & 8 \\
\hline
\end{tabular}

could happen due to the efficiency of nutrient taken up for the palms and the overall technical efficiency of the machinery (Corley and Tinker, 2003; Turner and Gillbanks, 2003). These losses perhaps could be improved by adopting better agricultural practices and utilisation of renewable energy resources.

\section{Economic Analysis of FFB Production}

The total production value, net return, benefits to cost ratio, and productivity cost were calculated using Equations (7), (8), (9) and (10). Table 6 depicts the input data for economic analysis that was sought from ERE (2012) and Azman et al. (2003).

TABLE 4. ENERGY INPUT/OUTPUT ANALYSIS OF FRESH FRUIT BUNCHES (FFB) PRODUCTION

\begin{tabular}{|c|c|c|c|}
\hline Input/output (yearly basis) & Unit & $\begin{array}{l}\text { Quantity per unit } \\
\text { area (ha) }\end{array}$ & $\begin{array}{c}\text { Total energy equivalent } \\
\left(\mathrm{MJ} \mathrm{ha}^{-1}\right)\end{array}$ \\
\hline \multicolumn{4}{|l|}{ A. Input } \\
\hline Human labour & hr ha $a^{-1}$ & 27605 & 54106.28 \\
\hline Machinery & hr ha ${ }^{-1}$ & 424 & 26574.38 \\
\hline Chemical fertiliser (NPK) & $\mathrm{kg} \mathrm{ha}^{-1}$ & 1924 & 172640.52 \\
\hline Herbicide & $\mathrm{kg} \mathrm{ha}^{-1}$ & 5 & 1150.00 \\
\hline Diesel fuel & & & 4000.00 \\
\hline Total energy input & & & 258471.18 \\
\hline \multicolumn{4}{|l|}{ B. Output } \\
\hline FFB & $\mathrm{kg}$ & 20000 & 160000.00 \\
\hline Total energy output & & & 160000.00 \\
\hline
\end{tabular}

an average of $20 \mathrm{t}$ of FFB ha-1 $\mathrm{yr}^{-1}$ based on certain considerations (Rankine, 1998).

Table 5 shows the calculated energy indices for FFB production. The index indicated that the performance of energy was utilised in the overall oil palm plantation activities and calculated by using Equations (3), (4), (5), and (6). The energyuse efficiency is $62 \%$, which showed that a unit of energy input produced 0.62 unit of energy output. The average energy productivity of FFB was 0.01 $\mathrm{kg} \mathrm{MJ}^{-1}$, which meant that 0.01 mass of unit output was produced by a unit of energy (MJ) input. More specifically, $13 \mathrm{MJ}$ of energy was required to produce a mass unit $(\mathrm{kg})$ of FFB. The negative net energy indicated that some energy was utilised for palm growth and perhaps minor losses. The losses

TABLE 5. ENERGY INDICES FOR INPUT-OUTPUT ANALYSIS

\begin{tabular}{lcc}
\hline Indices & Unit & Value \\
\hline Energy input & $\mathrm{MJ} \mathrm{ha}^{-1}$ & 258471.18 \\
Energy output & $\mathrm{MJ} \mathrm{ha}^{-1}$ & 160000.00 \\
Energy use efficiency & $\%$ & $61.90 \%$ \\
Specific energy & $\mathrm{MJ} \mathrm{kg}^{-1}$ & 12.92 \\
Energy productivity & $\mathrm{kg} \mathrm{MJ}^{-1}$ & 0.08 \\
Net energy & $\mathrm{MJ} \mathrm{ha}^{-1}$ & -98471.18 \\
\hline
\end{tabular}

The results of the analysis (Table 7) indicated that oil palm plantation business is still profitable at the price of RM $450 \mathrm{t}^{-1}$ of FFB (at cost of production in 2012). However, any increase in the production cost will slightly reduce its profitability. Thus, economic consideration is a vital component to analyse before any improvements could be suggested, such as applying green energy technologies for mechanisation practices.

TABLE 6. RAW DATA FOR ECONOMIC ANALYSIS OF FRESH FRUIT BUNCHES (FFB) PRODUCTION

\begin{tabular}{lcc}
\hline Economic data & Unit & Value \\
\hline Cost of production & $\mathrm{RM} \mathrm{ha}^{-1}$ & 5500 \\
Yield & $\mathrm{kg} \mathrm{ha}^{-1}$ & 20000 \\
FFB price & $\mathrm{RM} \mathrm{kg}^{-1}$ & 0.45 \\
\hline
\end{tabular}

TABLE 7. RESULT OF ECONOMIC ANALYSIS FOR FRESH FRUIT BUNCHES (FFB) PRODUCTION

\begin{tabular}{lcc}
\hline Economic component & Unit & Value \\
\hline Total production value & $\mathrm{RM} \mathrm{ha}^{-1}$ & 9000 \\
Net return & - & 3500 \\
Benefit to cost ratio & - & 1.64 \\
Productivity cost & $\mathrm{kg} \mathrm{RM}^{-1}$ & 3.64 \\
\hline
\end{tabular}




\section{Energy Analysis in Farm Mechanisation Operation}

From the observation, it was found that the mechanisation fleets were categorised into three main categories: infield FFB evacuation, mainline FFB transport, and field upkeep and maintenance. Table 8 summarises the data obtained through the survey. From the observation, it was understood that not all the visited plantations practiced mechanisation in all of their activities. Mechanisation is mostly practiced in evacuating the FFB from the palm bases to nearby mills.

Based on the observation also, it was also found that the plantations tend to equip their fleet with farm tractors and locally-made small farm utility vehicles and most of their fleets are powered by diesel fuel. Farm utility vehicles are usually used for infield operations such as hauling FFB from palm bases to the designated collection platform. Some of these machines are also used for spraying herbicide.
A bigger capacity farm tractor is usually used to evacuate FFB from plantations to nearby palm oil mills, but some tractors are also used for infield operations such as FFB evacuation (mini tractor Grabber), spraying herbicide or insecticide, and spreading fertiliser. The only limitation in utilising farm tractors is the topography, whereby certain tractors are not suitable for hilly areas due to small access paths between palms, especially when the terrace is not built for mechanisation practices.

The data on diesel consumption in oil palm mechanisation practices were analysed and the results are shown in Figure 4. The diesel fuel consumption per unit area for a specific job category such as FFB infield collection, FFB mainline transport, and field upkeep and maintenance is at 12.23 litres $\mathrm{ha}^{-1} \mathrm{yr}^{-1}, 21.4$ litres $\mathrm{ha}^{-1} \mathrm{yr}^{-1}$, and 9.46 litres $\mathrm{ha}^{-1} \mathrm{yr}^{-1}$ respectively. Thus, the total diesel fuel consumption is 43.1 litres ha ${ }^{-1} \mathrm{yr}^{-1}$ or equivalent to $2.4 \mathrm{GJ} \mathrm{ha}^{-1} \mathrm{yr}^{-1}$ as converted by Equation (2).

TABLE 8. SURVEY RESULTS IN SELECTED PLANTATIONS

\begin{tabular}{lcccc}
\hline \multirow{2}{*}{ Estates (location) } & Mechanised & \multicolumn{3}{c}{ Average diesel consumption (litre yr $\mathbf{r}^{-1}$ ) } \\
\cline { 3 - 5 } & area (ha) & FFB infield collection & FFB mainline transport & Upkeep \& maintenance \\
\hline Estate 1 (Ipoh) & 1360.80 & 12504.96 & 15888.96 & 24141.96 \\
Estate 2 (Batu Pahat) & 1203.14 & 43604.04 & 13527.96 & 241444.00 \\
Estate 3 (Teluk Intan) & 1505.12 & 14733.00 & - & - \\
Estate 4 (Kemaman) & 1120.00 & - & 115689.60 & - \\
Estate 5 (Sg Siput) & 163.87 & 540.00 & 8498.00 & - \\
Estate 6 (Renggam) & 947.20 & 3680.00 & 21997.33 & 27480.00 \\
Estate 7 (Kuching) & 868.00 & 784.00 & - & - \\
Estate 8 (Sibu) & 1033.20 & 24480.00 & 175601.85 & 77565.96 \\
\hline Total & 8201.33 & 100326.00 &
\end{tabular}

Note: FFB - fresh fruit bunches.

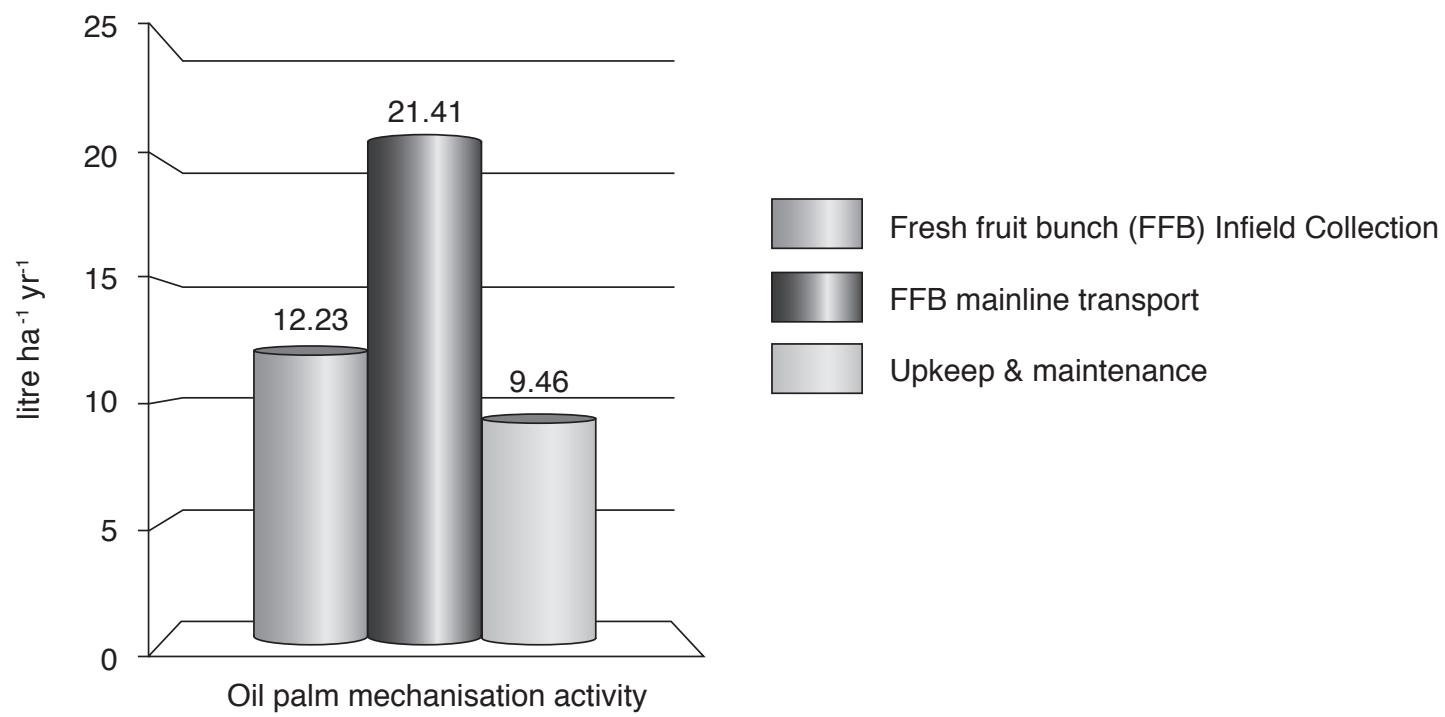

Note: FBB - fresh fruit bunches.

Figure 4. Diesel fuel consumption analysis on the selected activities obtained from the survey. 


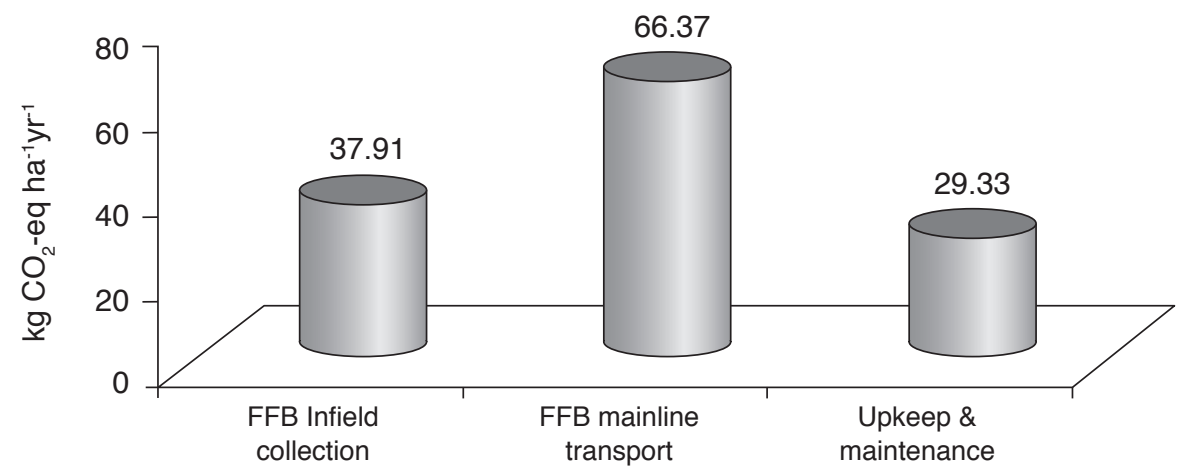

Note: FBB - fresh fruit bunches.

Figure 5. Result of greenhouse gas (GHG) emission from diesel fuel consumption for different oil palm mechanisation activity.

This figure is slightly different from the input data in Table 2, which was 3.2 GJ ha-1 $\mathrm{yr}^{-1}$ (Zulkifli et al., 2010). This difference might have occurred due to the consideration of the previous researcher on fuel consumption before and beyond the study boundary and time. The land preparation that utilise heavy machinery might require more fuel and this activity mostly occurs during new planting or replanting period (Stubbs, 2013; Jayaselan et al., 2011). Planting of legume cover crops also requires a substantial amount of energy. Thus, all of these factors could lead to those differences.

\section{GHG Emission in Diesel Fuel Consumption for Oil Palm Mechanisation Operation}

Environmental studies for oil palm plantation activities have been studied by various researchers such as Schmidt (2007), Nikander (2008), and Friedrich et al. (2011). GHG emission is always used to indicate gas emissions into the environment. For oil palm plantation, chemical fertiliser usually has the highest GHG emission, as it contributed the highest energy input. However, this current study only measured and focused on the amount of GHG emission from diesel fuel consumption in oil palm mechanisation operations. The GHG emission factor for diesel consumption was taken at $3.1 \mathrm{~kg}$ $\mathrm{CO}_{2}$-eq litres $^{-1}$ for emission related to the use of fossil fuels for oil palm plantation transport and machinery (Nikander, 2008). Figure 5 indicates the GHG emission for a specific job category in palm oil mechanisation practices. The results indicated that the GHG emission for FFB infield collection, FFB mainline transport, and field upkeep operation are 37.91, 66.37, and $29.33 \mathrm{~kg} \mathrm{CO}$-eq ha $\mathrm{hr}^{-1}$ respectively. In total, $133.61 \mathrm{~kg} \mathrm{CO}_{2}$-eq ha-1 $\mathrm{yr}^{-1}$ was produced from the direct utilisation of diesel fuel for oil palm plantation machinery. This figure is lower as compared to publish studied by Brinkmann (2009) that estimated the GHG emission for diesel fuel consumption in matured oil palm plantation was $180 \mathrm{~kg} \mathrm{CO}_{2}$-eq ha-1 $\mathrm{yr}^{-1}$ to $404 \mathrm{CO}_{2}$-eq ha-1 $\mathrm{yr}^{-1}$ based on a crude palm oil yield range of 3.2 to $4 \mathrm{t}$ $\mathrm{ha}^{-1} \mathrm{yr}^{-1}$. However, the values produced from that study had also included diesel fuel consumption for oil palm nursery operation and to provide power for office requirements.

\section{Potential Improvement}

The results of the analysis revealed that energy input is a crucial component in oil palm plantation operations, especially in producing FFB, whereby a large amount of energy, in terms of the nutrient, was required. However, other energy inputs are also important to improve the sustainability of the industry in term of an ecological perspective. It could also contribute to strategic positioning of the industry to the global markets.

Besides biodiesel, another potential renewable energy resource is solar energy and electricity generated from biomass energy for oil palm mechanisation practices. This renewable energy resource can be utilised as a source of energy for electric power train technology, which has been reported to have the ability to reduce operational costs and to improve the carbon footprint of oil palm products (Ludin et al., 2014).

Redpath et al. (2011) published their work on the implementation of solar charging an electric vehicle for agricultural purposes in the Mediterranean region. They concluded that the concept is efficient technically and economically for light duty operations such as chemical spraying, hauling agriculture input, and spreading fertiliser. It can be applied in Malaysia, as the country receives sunshine almost throughout the year. 
The electric power train technology is potentially used as a prime mover for crop-care and field maintenance activities such as herbicide spraying. It was reported by Darius et al. (2011) that a chemical-spraying prime mover can cover almost 8 ha per day of the operation compared to only 4 ha per day when using a 16 litres knapsack pump by only one operator with a fuel consumption of 3.14 litres $\mathrm{hr}^{-1}$. Thus, for an $8 \mathrm{hr}$ operation and $0.98 \mathrm{ha} \mathrm{hr}^{-1}$ effective field capacity, the fuel consumption was computed to be at 3.17 litres ha-1.

With this regard, if electric power train technology is employed or pursued, oil palm mechanisation operations could reduce its diesel fuel consumption to 6.26 litres ha-1 compared to the current utilisation of 9.46 litres ha-1 in upkeep and maintenance activities. The technology could also reduce $\mathrm{GHG}$ emission of up to $9.8 \mathrm{~kg} \mathrm{CO}_{2}$-eq ha-1. In terms of economic, electric power train technology is widely known as low maintenance and operational cost. Thus, it could benefit the industry in many areas.

\section{CONCLUSION}

The oil palm relies heavily on fertiliser input for its growth and productivity. However, improvement in the energy utilisation could potentially reduce the production cost and subsequently increase profitability. The inclusion of renewable energy source and cleaner energy technology in oil palm mechanisation practices will bring lots of benefits, since oil palm plantation requires a tremendous amount of energy, especially for palm growth up to 20 to 25 years.

Results of the energy utilisation in the oil palm plantations revealed that the total input energy required was almost $260 \mathrm{GJ} \mathrm{ha}^{-1} \mathrm{yr}^{-1}$ for a fully mechanised farm operation with $62 \%$ energy-use efficiency in producing an average of $20 \mathrm{t} \mathrm{ha}^{-1} \mathrm{yr}^{-1}$ FFB. The diesel fuel consumption was estimated to contribute $2.4 \mathrm{GJ} \mathrm{ha}^{-1} \mathrm{yr}^{-1}$ of the total input energy. In oil palm mechanisation practices, a higher GHG emission was contributed by hauling FFB from palm bases to nearby palm oil mills. Meanwhile, field upkeep and maintenance only contributed less than $30 \mathrm{~kg} \mathrm{CO}_{2}$-eq ha-1 of GHG emission. The application of a cleaner energy technology is expected to reduce $9.8 \mathrm{~kg} \mathrm{CO}_{2}$-eq ha-1 of GHG emission and with a substantial reduction in operational costs.

Finally, research in oil palm mechanisation operations should also emphasise in developing or utilising highly efficient machines in terms of its fuel consumption and higher effective field capacity. The machines should also be able to undertake several farm activities for optimal utilisation. Thus, it could reduce inefficient energy usage, as energy and farm input-output correlated to the highest degree. However, consideration should also be given to its economic viability before it could be implemented in the industry that contributes significantly to the Malaysian economy and prosperity.

\section{ACKNOWLEDGEMENT}

The authors would like to express their deep gratitude to MPOB for providing the facilities and financial support through the Graduate Students Assistantship Scheme (GSAS) Programme and to Solar Energy Research Institute (SERI), Universiti Kebangsaan Malaysia, Selangor, Malaysia for technical support.

\section{REFERENCES}

ABD RAHIM, S; MOHD RAMDHAN, $\mathrm{K}$ and MOHD SOLAH, D (2010). Small machinery in oil palm plantation. Proc. of the $4^{\text {th }}$ National Seminar on Oil Palm Mechanisation. MPOB, Bangi.

ABD RAHIM, S; MOHD RAMDHAN, K; ABD RAZAK, J; MOHD SOLAH, D; SALMAH, J and HITAM, A (2008a). Development of Mechanisation Standard and Benchmarks for Labour Efficiency in Oil Palm Plantation. MPOB, Bangi.

ABD RAHIM, S; MOHD RAMDHAN, K; ABD RAZAK, J; MOHD SOLAH, D; SALMAH, J and HITAM, A (2008b). Application of Soil Stabilizer for Plantation Road Construction. MPOB, Bangi.

ABD RAHIM, S; MOHD RAMDHAN, K; ABD RAZAK, J; MOHD SOLAH, D; SALMAH, J and HITAM, A (2009). Technologies for Oil Palm Harvesting, Evacuation and Loose Fruit Collection. MPOB, Bangi.

AVVAL, S H; ALI, M; SHAHIN, R and AHMAD, T (2012). Assessing the technical efficiency of energy use in different barberry production systems. J. Cleaner Production, 27: 126-132.

AWALUDIN, A; SALIM, S; ABIDIN, Z and NGAH, M R (2015). Performance study of an oil palm fresh fruit bunch (FFB) three wheeler evacuation machines. The Online J. Science and Technology Vol. 5 Issue 2.

AZMAN, I and SIMEH, M A (2012). An update on current labour situation in oil palm plantation sector. Proc. of the Palm Industry Labour: Issues, Performance and Sustainability Seminar. Kuala Lumpur.

AZMAN, I; SIMEH, M A and NOOR, M M (2003). The production cost of fresh fruit bunches: the case 
of independent smallholders in Johor. Oil Palm Industry Economic Journal Vol. 3(1): 1-7.

BRINKMANN CONSULTANCY (2009). GHG emission from palm oil production. A literature review and proposals from the RSPO Working Group on GHG. http: //www.rspo.org/ sites/ default/ files/ Report- GHG -October 2009. pdf>, accessed on 17 October 2012.

CORLEY, R H V and TINKER, P B (2003). The Oil Palm. World Agriculture Series. $4^{\text {th }}$ edn. Blackwell Publishing.

DARIUS, E P; YAHYA, A; ISHOLA, T; ROODI, S and HASSAN, H (2012). Oil Palm Mechanisation in Totality. International Conference on Agriculture and Food Engineering for Life, CAFEi 2012.

DARIUS, E P and YAHYA, A (2011). New mechanized system for circle spraying of oil palms seedling emergence. Scientia Agricola, 2 (69): 95-102.

ERE CONSULTING GROUP (2012). Study on restoration cost and return from oil palm industry. http: / / www.rspo.org>, accessed on 20 July 2015.

FLUCK, R C (1991). Energy in Farm Production. Elsevier, Amsterdam.

FRIEDRICH, D; PENA, N;BIRD, D N; SCHWAIGER, $\mathrm{H}$ and CANELLA, L (2011). Emission Balance of First and Second Generation Biofuel: Case Study from Africa, Mexico and Indonesia. CIFOR.

JAYASELAN, J and DESA AHMAD (2011). Development of mechanisation selection system for oil palm plantations with alternative planting pattern. J. Oil Palm Res. Vol. 23: 990-998.

LUDIN, NA; AZWAN, B; NORMAN, K; SOPIAN, K; SOLAH, D; HAMID, N H; ASIM, N and OTHMAN, Y (2014). Malaysian oil palm plantation sector: exploiting renewable energy toward sustainability production. J. Cleaner Production, 65: 9-15.

MONJEZI, N and ZAKIDIZAJI, H (2012). Energy and economic analysis of canola production in Iran a case study: Khuzestan province. Research J. Applied Sciences, Engineering and Technology, 3(4): 227-231.

MORTEZA, Z; OMID, M and AKRAM, A (2010). A comparative study on energy use and cost analysis of potato production under different farming technologies in Hamadan province of Iran. Energy, 35: 2927-2933.

MPOB (2014). Directory of Oil Palm Estates in Malaysia. MPOB, Bangi.
NIKANDER, S (2008). GHG and Energy Intensity of Product Chain: Case Transport Biofuel. Master Degree thesis. Helsinki University of Technology.

PISHGAR, $\mathrm{S} \mathrm{H}$; GHAHDERIJANI, $\mathrm{M}$ and SEFEEDPARI, P (2012). Energy consumption and $\mathrm{CO}_{2}$ emission analysis of potato production based on different farm size levels in Iran. J. Cleaner Production, 33: 183-191.

POLAT, R; COPUR, O; SAGLAM, R and SAGLAM, $C$ (2006). Energy use pattern and cost analysis of cotton agriculture: a case study for sanliurfa Turkey. The Philippine Agricultural Scientist, 4(89): 368-371.

RAHMAN, N A; ATAN, C M; LOW, R; BAINI, N F; CHE MAT and SALLEH, S F (2013). Study on the potential of palletisation of empty fruit bunch with sago as binding agent for power generation. European International J. Science and Technology, 2(2): 111-118.

RANKINE, I and FAIRHUST, T (1998). Mature Field Handbook, The Oil Palm Series. Vol. 3. International Plant Nutrition Institute.

REDPATH, A G; MCILVEEN-WRIGHT, D; KATTAKAYAM, T; HEWITT, N J; KARLOWSKI, $\mathrm{J}$ and BARDI, U (2011). Battery powered electric vehicle charged via solar photovoltaic arrays developed for light agricultural duties in remote hilly area in the Southern Mediterranean region. J. Cleaner Production, 19: 2034 - 2048.

SAHR, M B; ISHAK, W; YAHYA, A and WAN, C C (2005). Analysis of energy consumption in lowland rice-based cropping system of Malaysia. Songklanakarin J. Science Technology, 27(4): 819-826.

SANGLAM, C; TOBI, I; KUP, F and CEVIK, M Y (2012). An input-output energy analysis in pistachio nut production: a case study for South-eastern Anotolia region of Turkey. African J. Biotechnology, 8(11): 1868-1871.

SCHMIDT, J H (2007). Life Cycle Assessment of Rapeseed Oil and Palm Oil. Ph.D thesis. Aalborg University.

SHIRAZI, A M; AKRAM, A; RAFIEE, S; AVVAL, S H and BAGHERI KALHOR, E (2012). Analysis of energy use and relation between energy inputs and yield in tangerine production. Renewable and Sustainable Energy Review, 16: 4515-4521.

SINGH, S and MITTAL, J P (1992). Energy in Production Agriculture. Mittal Publications, New Delhi. 
STUBBS, B J (2013). Energy Usage of Agricultural Machinery for Corn and Soybean Production in Brazil, India, USA and Zambia. Master thesis, University of Illinois.

TURNER, PD and GILLBANKS, R A (2003). Oil Palm Cultivation and Management. Second edition. The Incorporated Society of Planters. Kuala Lumpur.

YUSOFF, B (2007). Palm oil production through sustainable productions. Eur. J. Lipid Sci. Technol., 109: 289-295.
ZULKIFLI, H; HALIMAH, M; CHAN, K W; CHOO, Y M and MOHD BASRI, W (2010). Life Cycle Assessment for oil palm fresh fruit bunch production from continued land use for oil palm planted on mineral soil. J. Oil Palm Res. Vol. 22: 887-894.

ZULKIFLI, H; HALIMAH, M; SUBRAMANIAM, $\mathrm{V}$ and CHOO, Y M (2014). Water footprint: part 2 FFB production for oil palm planted in Malaysia. J. Oil Palm Res. Vol. 26 (4): 282-291. 